\title{
Can we know the dancer from the dance?
}

\begin{tabular}{|c|c|}
\hline \multicolumn{2}{|c|}{$\begin{array}{l}\text { Book Title: } \\
\text { Closer than that }\end{array}$} \\
\hline closer 7 & $\begin{array}{l}\text { That } \\
\text { Ban That } \\
\text { DENDY }\end{array}$ \\
\hline \multicolumn{2}{|l|}{$\begin{array}{l}\text { Author: } \\
\text { Gail Dendy }\end{array}$} \\
\hline \multicolumn{2}{|c|}{$\begin{array}{l}\text { ISBN: } \\
978-0-9869982-0-1\end{array}$} \\
\hline \multicolumn{2}{|c|}{$\begin{array}{l}\text { Publisher: } \\
\text { Dye Hard Press, Sandton, } \\
2011,71 \text { p., ZAR105.00* } \\
\text { *Book price at time of review }\end{array}$} \\
\hline \multicolumn{2}{|c|}{$\begin{array}{l}\text { Review Title: } \\
\text { Can we know the dancer } \\
\text { from the dance? }\end{array}$} \\
\hline \multicolumn{2}{|c|}{$\begin{array}{l}\text { Reviewer: } \\
\text { Nicholas Meihuizen }{ }^{1}\end{array}$} \\
\hline \multicolumn{2}{|c|}{$\begin{array}{l}\text { Affiliation: } \\
{ }^{1} \text { Department of English, } \\
\text { North-West University, } \\
\text { South Africa }\end{array}$} \\
\hline \multicolumn{2}{|c|}{$\begin{array}{l}\text { Email: } \\
\text { nicholas.meihuizen@nwu. } \\
\text { ac.za }\end{array}$} \\
\hline \multicolumn{2}{|c|}{$\begin{array}{l}\text { Postal address: } \\
\text { Private Bag X6001, } \\
\text { Potchefstroom 2520, } \\
\text { South Africa }\end{array}$} \\
\hline \multicolumn{2}{|c|}{$\begin{array}{l}\text { How to cite this book review: } \\
\text { Meihuizen, N., 2013, 'Can we } \\
\text { know the dancer from the } \\
\text { dance?', Literator } 34(1) \text {, Art. } \\
\text { \#381, } 2 \text { pages. http://dx.doi. } \\
\text { org/10.4102/lit.v34i1.381 }\end{array}$} \\
\hline \multicolumn{2}{|c|}{$\begin{array}{l}\text { Copyright: } \\
\text { @ 2013. The Authors. } \\
\text { Licensee: AOSIS } \\
\text { OpenJournals. This work } \\
\text { is licensed under the } \\
\text { Creative Commons } \\
\text { Attribution License. }\end{array}$} \\
\hline \multicolumn{2}{|l|}{ Read online: } \\
\hline 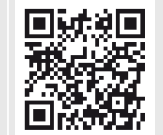 & $\begin{array}{l}\text { Scan this QR } \\
\text { code with your } \\
\text { smart phone or } \\
\text { mobile device } \\
\text { to read online. }\end{array}$ \\
\hline
\end{tabular}

This collection of poems comprises four numbered but unnamed sections, leaving it up to the reader to determine the significance of this formal structure. The first section might be thought of as dealing with perspectives onto various types of creativity, including the creation of earthly existence according to the mock-theology of the demiurge in the first poem, 'The Apprentice' (pp.9-10). Other areas include writing ('To Write or Not To Write' [p.11]), trapeze work ('The HighWire Artist' [p. 12]), and ballet ('Swan Lake' [p.13]). To disturb my neat categorisation, the section also provides perspectives onto past school-acquaintances ('Linda' [p. 14]), love ('Constancy' [p. 15]), 'Vertigo' [pp. 19-20]), and, with a backward glance at Wallace Stevens, fruit ('Ruminations on the Plum' [pp. 16-17]). Part II might be read as concerning objects, poems, amethyst, skin, cats, the sun, computers and books (pp. 23-35). Part III deals with the self's relation to activity and to others (pp. 39-54), whilst Part IV concerns itself with the self's relation to a wider world (pp. 57-71).

Of course, the moment one tries to delimit the significance of a structure, the inadequacy of doing so becomes apparent, and the reader appreciates the poet's use of numerals rather than titles - they give a pace to and, more importantly, a place for the reading. The numerals provide compartments in which to dwell for a time, until the resonances within the parts become clearer, and the structural logic of the arrangement justifies itself from within, rather than being imposed from without. As always, in this book too, one has to live with poetry, not just read it once or twice, in order to appreciate it. And Dendy warrants re-reading. Her style is lucid, her language and images accessible, even when meanings are not immediately apparent. My one complaint is that some poems, whilst they might contain intriguing ideas (I think of 'The Apprentice', which provides a comic cause for a bungled creation), have throwaway lines which, although in keeping with the necessary lightness of touch required in this particular poem, are simply not memorable. The demiurge in 'The Apprentice' 'tried to say sorry' for the 'bloody disaster' he or she or it caused (and here comes the final line, the supposed climax of the poem): 'I did. I really, really did' (p. 10).

The book is noteworthy for the lively intelligence that Dendy always shows, even in those poems that present themselves as 'throwaway' poems (in reality, no poem good enough for publication is 'throwaway'; they all require intense effort in the writing). This is best exemplified through a few extracts. Here is one from the beginning of 'Amethyst', which reminds me of aspects of Neruda's Sky Stones:
The potted violet is blooming again,
its miniature florets feathering out
like scattered amethysts on a sea-green floor.
It opens like a breath underwater.

The interplay between the tetrameter beat and the varying feet - amphibrachs, dactyls, trochees, and iambs - creates a delicate rhythm, which takes its cue from the polysyllabic cluster in the eponymous 'amethysts'. The modulation amongst images is very fine, being at once descriptive, kinetic, and imaginatively transformative, where breath inhabits an element that should be foreign, but is in perfect accord with what went before.

Dendy is herself a dancer, and how well she inhabits the movement, the at-oneness of dancer and dance (to draw on Yeats), in the words of one of the poems in this book, 'Circles':

\footnotetext{
The fire encircles the dancers,

and the dancers are like flames,

and their feet are flames

and their skirts are like the circles

when rain beats on the water,

and the water dances
}

to the sound of the rain, and in silence 


\section{the rain stops dancing}

in its silver circles,

and so the dancers are gone,

and you are a solitary, whirling flame. (p. 52)

Her inhabiting of the dance is also, we realise by the end of the poem, an internalisation of the dance by the writer, to the point of identification with the flame (which originally was likened to the dancers): 'and you are a solitary, whirling flame'. The second person pronoun here empties selfhood, underlining absorbed identification with the 'whirling flame'. Interesting, as in 'Amethyst', is the presence of 'water'. Coterminous with flame, it helps signal the transitivity amongst radically different elements, a figurative pliancy, which extends into the transformation of form into movement, and the inhabiting of sense almost void of consciousness (being the 'flame' in an after-effect kindled by the dance). For me, this is Dendy at her best, the poet whose formal elegance can celebrate an interpenetration of formal boundaries, whose vision thrives on the fluid effects of suggestion.

This volume will appeal to readers of contemporary poetry who value accessibility allied to intellectual acuity and emotional sensitivity. It is also a fine example of the flowering of poetry in South Africa over the past two decades, especially amongst female poets. 